\title{
Leadership on the board: the role of company secretary
}

Book or Report Section

Accepted Version

Kakabadse, A., Khan, N. and Kakabadse, N. (2017)

Leadership on the board: the role of company secretary. In:

Storey, J., Hartley, J., Denis, J.-L., t' Hart, P. and Ulrich, D.

(eds.) The Routledge Companion to Leadership. Routledge, Abingdon, pp. 241-259. ISBN 9781138825574 Available at https://centaur.reading.ac.uk/68907/

It is advisable to refer to the publisher's version if you intend to cite from the work. See Guidance on citing.

Publisher: Routledge

All outputs in CentAUR are protected by Intellectual Property Rights law, including copyright law. Copyright and IPR is retained by the creators or other copyright holders. Terms and conditions for use of this material are defined in the End User Agreement.

\section{www.reading.ac.uk/centaur}

\section{CentAUR}

Central Archive at the University of Reading 
Reading's research outputs online 


\title{
Leadership on the Board The Role of Company Secretary
}

\author{
Andrew Kakabadse, Nadeem Khan and Nada Kakabadse
}

\section{Introduction}

This chapter explores how the role, power and influence of the company secretary ${ }^{1}$ relates to other board members (chairman, chief executive officer (CEO), senior independent director (SID), non-executive director (NED)) in helping the board make better decisions. An analytical framework is developed that depicts this role's heterogeneity and characteristics pertaining to effective leadership practices.

So: why the company secretary? The roles and responsibilities of chairman, CEO, Chief Financial Officer (CFO), SID and NED are legislatively more developed, formally recognised and regularly evolved within governance, and are widely researched as leadership practices. Indeed, individuals in these corporate roles often become household names in media headlines on business successes or failures. Typically the chairman-CEO relationship has received much attention, while, emerging from the recent financial crisis of 2008, the NED role has re-gained prominence. In contrast, the company secretary role remains legislatively less well defined and subject to limited regulatory evolution. This role's relationship to leadership practice is hardly researched (Cadbury, 2002; Roberts, 2002; Muller etal., 2007) and lacks empirical investigations (ErismannPeyer et al., 2008). Can you name or recognise a company secretary in media circles? Yet, in this chapter, it will become clear that the company secretary not only has a long and majestic history, but is now also likely to be the longest-serving person in the boardroom. The company secretary is usually the first to know, and be closest to, the most up-to-date critical information; ideally placed as the key link between board/executive and chairman/other board members; and centrally involved in board processes (Finkelstein and Mooney, 2003) and agendas. If the company secretary role's relationship to board leadership practices can be better understood as the 'building block' or 'genesis' for addressing the problematic, then the other roles are more easily aligned in achieving consensus. Illustrating the main question through a company secretary lens, two wider questions are brought into focus: why are the expectations from other board members about the company secretary role unclear, and how should boards relate to leadership practice?

To address the main question and two wider problematic issues of the role's link to leadership practice, this chapter will explore the role, power and influence of company secretaries through in-depth semi-structured interviews from mainly FTSE250 boards. These interviews 
took place in 2014 and reflected on the post-financial crisis developments in the role and leadership practices of the company secretary.

\section{Role within a Board}

What does a company secretary do? Typical existing studies outline the role of company secretary as having formal responsibilities such as organising board meetings; supporting the chairman/CEO, directors and stakeholders; inducting or training non-executive directors; dealing with latest governance developments; board evaluations; annual reporting; statutory compliance issues; administrative duties; accurate Companies House filing; and stock exchange listing. However, the focus in this chapter is more on the informal aspects of the role. The company secretary has to adopt additional higher-order skills when relating to leadership practice. The company secretary's challenge is to resolve tension between being the invisible power behind the throne, i.e. in the shadow of the chairperson, and knowing how to diplomatically challenge individual board member effectiveness towards higher collective board performance. This includes resolving dilemmas, dealing with complexity, making judgements, acting as advisor and/or confidante, and maintaining high levels of trust. The breadth of knowledge and diplomatic skilfulness of the company secretary must balance crafting of relations with, and between, self-assured personalities (chair, CEO, CFO, SID, NEDs) and not expressing ego in oneself.

Few would doubt that boards are an established governance mechanism, protecting the principals' interests (Fama and Jensen, 1983) and acting as 'large, elite, and episodic decisionmaking group/s' that are networked to perform complex tasks in the realm of corporate strategy (Forbes and Milliken, 1999). This makes the role of company secretary particularly critical, as it is the crucial link that binds the other board roles together as a body; it always protects the interest of the company and tries to seek consensus amongst the board members as a leadership practice. This becomes even more critical when excessive 'prozac leadership' (Collinson, 2012) often conceals power asymmetries and top-down control as a contribution to toxic or destructive behaviours (Schyns and Hansbroughn, 2010; Padilla et al., 2007). Although, within post-heroic leadership practices (Briskin, 2011) the more 'heroic, charismatic and egoistic' leadership roles may receive prominent attention (Fletcher and Kaufer, 2003), it is the more invisible (Ladkin, 2013), facilitative, interpersonal relational power of the company secretary that becomes politically critical in a major change or crisis situation (Van Essen et al., 2013).

Presently, in the Anglo-Saxon context, the 'company secretary'(UK) is legally perceived as an 'officer' of the company. It is an executive position that usually reports directly to the chairman and is the key point of contact for other board members. Actually, this occupation is an old art that can be traced back to its earliest predecessors of some 5,000 years ago in terms of its activities, such as registration, administration and organisation (Schlott, 1989). Despite this, today we typically more often refer to the East India Company (1600-1833/57) as the first joint-stock entity, with Seth's (2012: 222) analysis asserting that 'the past has the capacity to explain the present' contemporary corporate behaviours and issues. However, the inner workings of boards are mostly confined to those participating in their meetings, rendering empirical research limited. Within this sanctum, the company secretary has always been present but is largely ignored (McNulty and Stewart, 2014; Hilb, 2011) resulting in a paucity of research on this role.

\section{Invisible Leadership Practices}

In pursuing a study of the role in relation to leadership practice, we use a broad-minded lens of power (Pettigrew, 1992). This is a subjective approach that overcomes the limitations of 
confining leadership to formal attributes only, such as a simple legal role, managerial thinking or boxed quantitative rationalisations. It allows for a more holistic, meaningful, understanding of the higher-order skills, competencies and informal attributes that are needed by the company secretary in practising governance and leadership. Pettigrew (1992) argues for considering the board as an open system and that studies of board roles should not be separated from studies of power in institutions and society, nor from studies of the composition and attributes of top management teams. Others argue that research should expose the hidden dynamics of boardrooms (Van der Walt and Ingley, 2003). Understanding the role via this lens allows for both formal/informal practices and multi-level influences on the role to be considered as behaviours (van Ees et al., 2009). Other studies have adopted a spatial governance perspective (McNulty and Stewart, 2014); our emphasis, however, is on interpreting organisations as being more complex, and consisting of people with less predictable attributes, particularly in the range of leadership roles (Balkundi and Kilduff, 2006).

As such, in this study the definition of leadership practice is focused on how the company secretary uses 'role, power and influence' (Pettigrew, 1992; Lukes, 1974) to affect board decision-making. This broader definition enables the exploration of the informal, discrete, third-dimensional aspects of power, which can influence policy and board outcomes. These leadership practices take place behind the scenes; they are political or relational aspects beyond the typical formal role. Our findings explore the subtle, moral and relational dilemmas that the company secretary faces. The semi-structured interviews we conducted demonstrate how variably company secretaries operate, exercise power, and influence dynamics at board level within and outside the boardroom. We term these practices invisible leadership.

Attention is given to how the company secretary deals with power plays within the board and organization. In so doing, how is the company secretary's role exposed to the decisionmaking processes within the board? We analyse the notion of discretion in the company secretary's role, and take account of structure and processes in relation to influencing the board of directors, helping them make better decisions.

\section{Historical Development of the Role}

The position of company secretary has a rich history. Ancient scribes, who were involved in all matters of writing, embodied functions which are precursors to those of the modern company secretary (Boylan, 1922). From an organisational perspective, the role's ancient, informal origins can be traced to the Egyptians ( $3000 \mathrm{bce}$ ) although it did not achieve formal legal status until 1841. The most significant recorded company secretary developments stem from the colonisation period of 1550 to 1650, which saw the rise of the English Levant and East India Companies (Kaye, 1853; Adams, 1996; Gepken-Jager et al., 2005). The Pontifex v Bignold case of 1841 set a precedent related to the power of the company secretary. More recently, the duties and responsibilities of the role were more closely defined (Monsted and Garside, 1991; Cadbury Report, 1992), followed by a phase of wider legal and regulatory enhancements (Daigneault, 2006).

In the English Levant Company (formed in 1581), the company secretary held considerable powers, such as commanding actions to be performed in Her Majesty's name (Epstein, 1908: 74). In the East India Company (formed in 1600), the secretary post at its London-based headquarters became the 'Secretary of State', with the power to control the proceedings of the company. The secretary post on the trading side was responsible for the administration, registration and implementation of acts of parliament, and was given the task of exercising the stipulations from the Supreme Court of Judicature (Kaye, 1853: 131; Ramaswami, 1983: vi-viii). In the Dutch East India Company (formed in 1602), the company secretary at headquarters held a dual 
role as secretary of the board and as the board's advocate and advisor on legal matters (Schmidt etal., 1988: 58; Gepken-Jager etal., 2005: 52). At the same time, the secretary at the trading company held extensive and concentrated legislative and executive powers (Naval, 1920: 248-249).

The collapse of the Levant and East India Companies marked the end of the monopolistic trading company with powers to execute sovereign rights (Schmidt et al., 1988: 6), which dramatically reduced the power exercised by the company secretary. No longer did this role combine the affairs of state and company. The powerful political duties of the company secretary, granted by the state and parliament, were decoupled from the duties covering company affairs. From then on, the role of company secretary has focused on narrower commercial, economic and legal affairs.

During the period 1750-1850, the company secretary resumed the role of 'servant' of the corporation and 'secretary of the society' with specialised tasks (transferring company shares; seconding resolutions; registering share transfers; acting on behalf of the company; handling unclaimed dividends; and deleting member names from the company registers) but without the authorisation and responsibility to represent the company externally (Pontifex v Bignold, 1841; Severn \& Wye \& Severn Bridge Railway Co, 1896). In the period 1900 to 1950, judicial outcomes such as Panorama Developments, Guildford, Ltd v Fidelis Furnishing Fabrics Ltd, 1971 redefined the company secretary as an officer of the company connected with administrative affairs, thus determining the 'profession's duties and responsibilities' (Monsted and Garside, 1991: 4).

The corporate scandals of the 1980s led to renewed stress on regulation and corporate governance (Cadbury Report, 1992), thereby expanding the duties of the company secretary. Around 2000, the role expanded to include certain corporate governance responsibilities (Murphy, 2003; Monks and Minow, 2004; Daigneault, 2006). The company secretary today has responsibilities as outlined in the introduction. These responsibilities-include ensuring that the corporate entities meet governance requirements (Companies House reporting); following procedures set out in law (formal board meetings; appointments; reporting); and ensuring stakeholder satisfaction (shareholders/directors /media) - become critical to company interests in major change or crises situations. In highly regulated and competitive environments such as that of the UK (Burton, 2000), boards as top teams are always under pressure to perform well and meet shareholder and wider stakeholder expectations. The company secretary has to learn to deal with and manage power relations at this level within and outside the organisation as a form of leadership practice.

The company secretary as corporate governance officer (Steger and Bottger, 2008; Filiz 2013) has the responsibility to raise the question 'What is the right thing to do?' (Gallagher, 2002: 41) and is in a prime position to make these judgments and then advocate them with management and the board' (Gallagher, 2002: 42). These days, the professional bodies such as the Institute of Chartered Secretaries and Administrators (ICSA) ${ }^{2}$ (Armour, 2012) and other associations, such as the Institute of Directors, UK (Ashton, 2008) are politically critical to the standing of the role amongst the board members and the development of the role and its responsibilities.

The history of the development of the company secretary role suggests that it has influential importance, particularly post-crisis when there has been renewed attention paid to its responsibilities. There is criticism, however, that the power of the role remains constrained, under-utilised and/or misunderstood.

\section{Power of Company Secretary}

Lamm (2003: 24) argues for the company secretary's dual role, being 'inclusive of corporate governance function', as the optimal position in the organisation. The law defines the company 
secretary as an officer with administrative duties and responsibilities, but because of its foundation in law, this role sets the tone for, and is central to, the provision of an underlying internal framework for corporate governance structures (Filiz, 2013). Hence, the company secretary is required to provide administrative and legal governance support to the board of directors and the CEO (Lamm, 2003).

In order to be effective, the company secretary must maintain direct relations with these two different sets of actors at the 'apex of the firm's decision control system' (Fama and Jensen, 1983) to act as a protector of the interests of the principals' (board directors) and the management (agents). Scholars posit that powerful boards are desirable as this increases their ability to monitor and control the CEO's actions (Chen, 2007; Petra, 2005) as part of overseeing corporate governance execution (Finkelstein et al., 2009). Due to more frequent interactions, the prevailing relationships of the company secretary are more likely to be with the board of directors. This positioning does not diminish the influential link the company secretary provides between the board, individual board members and executive management, often acting as the impartial moderator or mediator.

It is further recognised that the nature of the company secretary's role and activities is influenced by external (i.e. statutory and regulatory requirements) and internal (i.e. procedures such as company-specific articles of association/by-laws; company policies; employment contracts) factors. The extent of these interactions depends upon the individual in the role of company secretary and how he/she responds to changes in formal structures and to new requirements as demanded by the role (Beattie, 1980), along with how the role itself fits, and has been developed, within the company. The unique behavioural demand lies in balancing information requirements and communication effectiveness. The company secretary needs to engage with internal and external stakeholders; negotiate critical and asymmetric information between different interests; and balance the board and management interface in a way that avoids undue antagonism, placates differences, and achieves alignment between the demands of two, and often more, bipolar cultures.

The role is mandatory for publicly listed companies, which are obliged to follow statutory and reporting requirements (Dubs, 2006). Beyond that, there is flexibility and discretionary capacity. Characteristics and required competencies include administration, business awareness, communication skills, compliance, guidance, information impact, knowledge shaping, maintenance, management, organisation, process, procedure, qualification, relationship, and shareholder and stakeholder engagement (Vance, 1983; Hannigan, 2009). Activities include keeping the company register, filing, recording, monitoring, supervising, educating, advising, managing, and co-ordinating. The combination of characteristics and activities forms the unique and specific company secretary role and its related functions (Vance, 1983; ICSA, 2012). Although the 'precise duties of the company secretary are not generally prescribed by statute - they will usually need to be set out in his/her contract of employment' (Morris et al., 2009: 223).

As it channels information flows between the board of directors and executive management, the role is significant to board members as an 'up to date source of information' (Kakabadse et al., 2014). The company secretary manages the information flow. Planning formal communications with board members requires an understanding of who needs to be informed; what information is needed; how to present it; and the frequency and form of communication (Herbert, 1977). The process is designed to influence opinions, perceptions and relationships, and/or to initiate board and management team actions. It is the company secretary who is most likely to be closest to the dynamic holistic agenda and who understands the more subtle informal individual preferences, personalities and likely reactions. 
Although the company secretary often has a low profile in the boardroom, the role is critical to board resolutions and actions. In the majority of cases, it is the preparatory work in advance of board meetings that influences outcomes, enabling the conversion of strategy into implementable action plans (Arnold, 1987). Preparatory work influences the frequency, venue and duration of board meetings; interactions between the $\mathrm{CEO}$ and the board; finding solutions to issues; ensuring a level of consensus among directors; the form and technicalities of board proceedings; and involvement of boards in self-evaluation (Zahra and Pearce, 1989; Vance, 1983). It is the company secretary who facilitates timely meetings; ensures the discussion of issues to the required depth; respects disagreements between directors; ensures that directors participate in the decision-making process rather than just ceding the decision to the CEO; and ensures that minutes are well formulated and documented to monitor progress (Zahra and Pearce, 1989: 310; Vance, 1983: 24-27).

Recent research identifies the company secretary as the lynchpin in the communication process between the CEO and the board (Kakabadse et al., 2014; Baron and Kenny, 1986), overcoming inadequacies, manipulation, reliability issues or delays that may impede board effectiveness (Zahra and Pearce, 1989; Kakabadse et al., 2010). This often extends to the company secretary being the third person in the CEO-chairman relationship. Whereas the CEO has hierarchical authority, the chairman is primus inter pares, the first among equals (Levrau and Van den Burghe, 2013: 108) as head of a collegial body. This allows the company secretary's extensive discretionary influence to exercise relational power. This may be in the way that or level of detail in which information is presented or communicated, catering to different preferences or needs. Or it may be in the way information is prioritised/selected as being important enough to warrant discussion in a board meeting.

Macro-analysis focuses attention on sources of power such as position, expertise, access to information, motivation and rewards (Pettigrew, 1972). More subtly, the ability of an individual or group to realise their intended effects is related to their capability of leveraging relational/micro-aspects of power, which are contingent on the degree of dependency (French and Raven, 1959) or currency to make connections and appropriately influence others (Pettigrew, 1972). Thus, the power capability of the company secretary requires behavioural analysis (Cyert and March, 1963; Huse, 2005) of those involved, coupled with structural positioning of roles held (van Ees et al., 2009; Dalton and Daily, 1997; Roberts et al., 2005).

The power of individuals within a group is primarily derived from five sources: reward, punishment (coercion), legitimacy, knowing other people (referent) and having expert skill or knowledge (French and Raven, 1959; Raven 2008). More widely, Giddens (1984) asserts that power is of central, if not exclusive, importance to the 'Constitution of Society', a component of social structure exercised by human agents with the capacity to enable or constrain each other. Consequently, knowledge is not objective, but an outcome of continuous negotiation between individuals, reflecting an inseparable link between subject and object (Sandberg, 2005). As such, the company secretary possesses knowledge not only of processes and procedures, but of associated 'corporate memory', enabling greater indirect ability to influence board-level decision making through less observable behaviours, and acts of consensus-building and prevention of conflict (Kakabadse et al., 2014).

Steven Lukes's (1974) typology of the three dimensions of power is a useful analytic for demonstrating a fundamental distinction between decisional and non-decisional exercises of power within the boardroom. Lukes (1974:23) observes that 'the most effective and insidious use of power is to prevent conflict from arising in the first place'. Importantly, a lack of conflict and the appearance of consensus do not equal the absence of power relations. That is, those subject to power can be 'socialised' into a false appreciation of their real interests, and thereby act against them, whilst believing that they are acting according to their preferences (Young, 1978). 


\section{Third-Dimensional 'Smart Power'}

Exploring the dynamics of power within the boardroom elite and episodic decision-making in group interactions provides new insight into informal leadership practices such as managing information flow, dealing with personalities, negotiating the possible outcomes, and managing company interests and individual expectations, all as views of power. The discrete, informal processes of elite communication, socialisation, acculturation and fraternisation are central to any understanding of board consensus (Pettigrew, 1992). Power relations within elite settings such as the boardroom tend to reinforce and perpetuate the dominant logic. However, it is important to recognise that the legitimised constructions that form the social context of boardroom interactions are far from absolute; individuals have strengths, weaknesses and different agendas, making decision making politically complex (van Ees et al., 2009).

Drawing on Lukes's (1974: 2005) concept of third-dimensional power, this study considers the discrete mechanisms of preference formation at play within boardroom elite interactions. How does the company secretary deal with power plays within the board and the organisation? How is the company secretary's role exposed to the decision-making process within the board?

Lukes (2005) argues that we need to think about power broadly and pay attention to those aspects of power that are least accessible to observation. Power is an imposition of internal constraints; those subject to it acquire beliefs that result in their consent, or their adaptation, to domination, in its either coercive or non-coercive forms.

The first dimension of power is actual observable behaviour (Dahl, 1957; Polsby, 1963) in situations in which the powerful prevail. The second dimension of power has observable instances of control through 'soft initiatives' and is about control over non-decision making, i.e. 'where demands for change... can be suffocated before they are even voiced, or kept covert' (Bachrach and Baratz, 1970: 44). This introduces 'mobilisation of bias' (Bachrach and Baratz, 1962: 948) as a prevailing set of subjectivities (values, beliefs) of one group over another, e.g. strategic agenda setting grounded in matters outside the boardroom. Such pre-decisional activities are of critical importance in determining the decisions that will, ultimately, be made down the line (Cobb, 1983; Rose-Ackerman and Long, 1982).

The third dimension is where the supreme exercise of power is to get others to have the desires you want them to have' (Lukes, 1974: 23). The powerful can symbolically or covertly shape agents' awareness of their interest and ability to act. This operates at an ideological, normative level, at which interests remain concealed. This may be at work somewhere within, and between, the structural determinants of the boardroom and the issue definition and agenda-setting activities as a boardroom process (Table 16.1).

Applying Lukes's (1974) third-dimensional or 'smart power' to the company secretary role provides insights into the less obvious, subtle, relational and political aspects that are usually behind the more formal overt elite boardroom interactions and their consensus-formation activities. Smart power is exercised through sensitive diplomatic dialogue, in which endurance is underpinned to build trust, which should be at the core of effective boardroom interactions. Consensus building emerges as covert, informal, massaging, positioning and posturing of strategies that unlock or reinforce structural resistances to dynamic change. The company secretary, with unique direct relations to board members and executives, has discrete power over the desires and beliefs that shape boardroom dynamics. Thus, this radical conceptual mechanism suits the exploration of the questions of whether, and how, the preferences of elite participants have been influenced without their knowledge.

In her commentary on boardroom practice, Baroness Kingsmill (2008: 24) notes that the company secretary is 'the best guide to board etiquette', through their role of servant of the 
board and employee of the company. The company secretary has often served under a number of CEOs and chairmen and as such 'can be an important source of information and guidance' (Kingsmill, 2008: 24). The company secretary takes the minutes, so if a board member wants to ensure that his/her points are recorded elegantly, they need to 'become their friend' (Kingsmill, 2008: 24). At a deeper level, the company secretary's invisible leadership as lessons of 'service' stands out from following meagre rules and hierarchical titles, to help others create meaning and purpose by engaging moral and human dimensions to the bigger picture and in not allowing leadership to 'begin and end with themselves' (Sena et al., 2013: 41).

Here we draw upon evidence from a study that was informed by 40 one-to-one semi-structured qualitative interviews with company secretaries, chairmen, CEOs, NEDs and independent

Table 16.1 Three Dimensions of Power

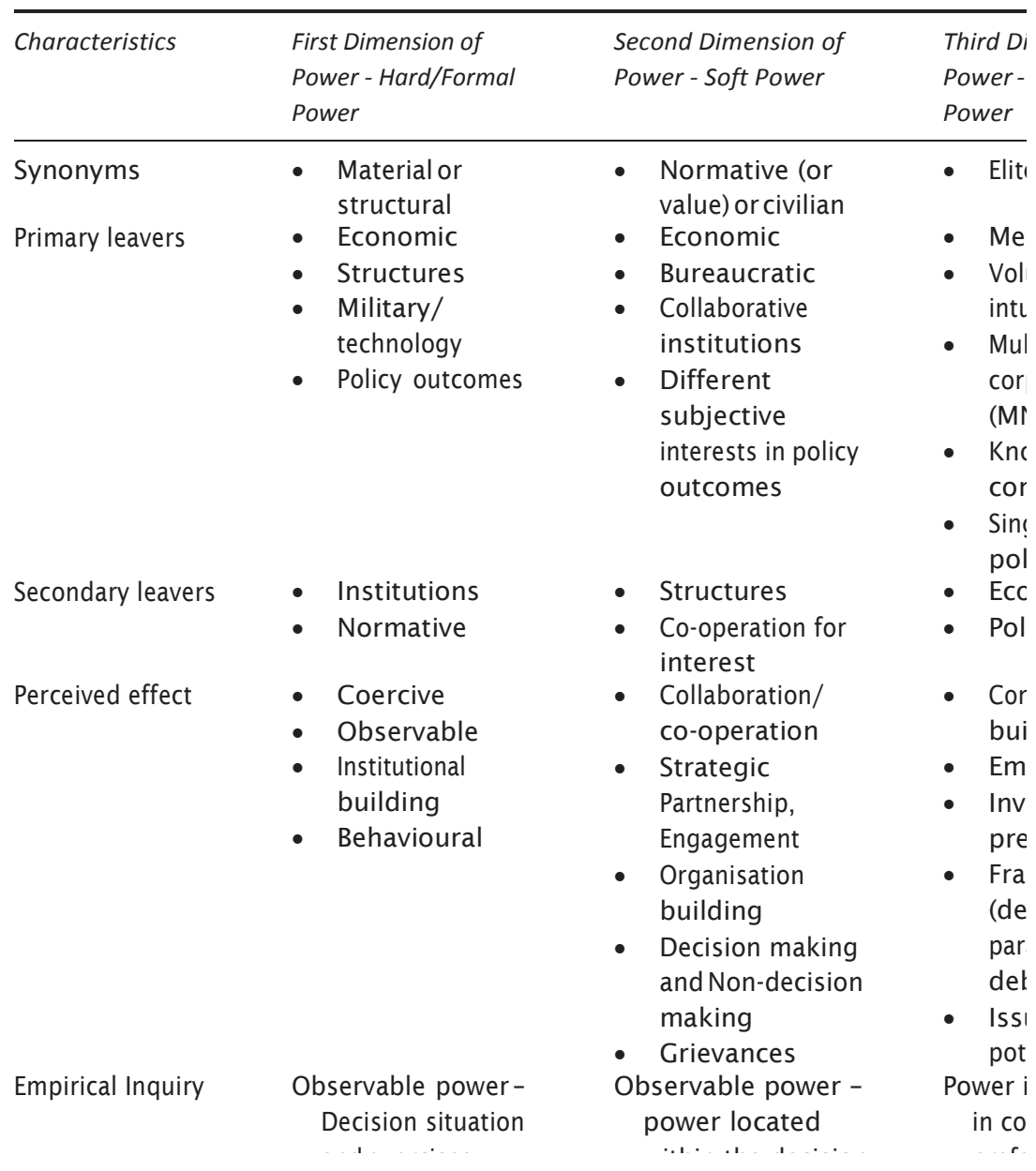




\section{Conceptualisation of power}

\author{
'The ability of $A$ \\ to get $B$ to do \\ something he \\ or she would \\ otherwise not do' \\ (Dahl, 1957: 202)
}

\author{
'Is also exercised \\ when A devotes his \\ energies to creating \\ or reinforcing social \\ and political values \\ and institutional \\ practices that limit \\ the scope of the \\ political process to \\ public consideration \\ of only those \\ issues which are \\ comparatively \\ innocuous to $A^{\prime}$ \\ (Bachrach and \\ Baratz, 1962: 948)
}

\author{
'A may exercise \\ power over B by \\ getting him to do \\ what he does not \\ want to do, but \\ he alsoexercises \\ power over him by \\ influencing, shaping \\ or determining \\ his very wants. \\ Indeed, is it not the \\ supreme exercise \\ of power to get \\ another or others \\ to have the desires \\ you want them \\ to have?' (Luke, \\ 1974: 23) \\ Schattschneider (1975); \\ Lukes (2005)
}

$\begin{array}{cccc}\text { Influential authors } & \text { Dahl, 1957; Polsby, } & \text { Bachrach and Baratz } & \text { Schattschneider (1975); } \\ 1963 & (1962) & \text { Lukes (2005) }\end{array}$

Source: compiled by the authors.

consultants, which were facilitated through focus group sessions (12) and distributed questionnaires. The one-to-one interviews lasted, on average, 70 minutes each, whilst the focus group sessions were designed for two hours each and consisted of between 5 and 20 people per session. Participants were purposefully selected from the ICSA register. A total of 206 participants provided detailed accounts (Harre and Secord, 1972; Kakabadse and Louchart, 2012) of their beliefs about and experiences and perceptions of the company secretary.

The unit of analysis is the individual company secretary. All interviews and focus group sessions were recorded and transcribed; the less detailed questionnaire responses were taken as written responses. The inquiry process interpretively analysed interviews/focus groups/questionnaires reflectively, seeking the deeper inter-subjective meanings of the third-dimensional 'smart power' that underpins boardroom elite interaction and consensus formation.

The primary interest was to achieve understanding of a company secretary's exercise of power, rather than to explain and predict their future behaviours. With this perspective, the view was taken that nothing was trivial in company secretary interactions with relevant others, and that everything they do has the potential for unlocking understanding about the exercise of their power (Janesick, 1994).

Qualitative data analysis (Miles and Huberman, 1994) by the Henley Business School research team used open coding techniques to assign descriptive phrases. Several themes emerged within the interview narratives (Corbin and Strauss, 1990). Discrepancies were resolved through intensive discussions within the team as part of the iterative development process. This allowed for how company secretaries perceive themselves and how other board members perceive and define the company secretary at the board level.

Finally, a focus group session with study participants was convened, which verified the findings through presentation and participative discussion.

Three major themes, each with sub-themes, emerged from our analysis, namely: company secretary's role, power and influence as invisible leadership or third-dimensional power. 


\section{Company Secretary's Power}

In this section, the themes that impact on the third-dimensional invisible role, power and influence of the company secretary are shared.

\section{Role}

Each organisation and board is unique. A company secretary's power depends on their ability to negotiate structure and position the role in a way that is effective for them within the team:

You're not a member of the executive team, you're not a member of the board, you're the interface between board and executive, you've got to have independence.

Co.sec.

A higher level of self-confidence and assuredness within the elite cadre is required, particularly as board members often misunderstand or lack awareness of the role of the company secretary:

You have the same liabilities as executive directors, butyou don't sit on the board but are trusted to sign everything... I'm not someone's secretary, I am the Company Secretary which is different.

Co. sec.

The associated history and self-moulding of the role affects the power the individual wields within the group context, and to what extent personal skillsets drive duality or wider commitments:

As general counsel you are heavily involved in the running of the business and are the chief executive's right hand. This is different to being the chairman's right hand as company secretary.

Co. sec.

The company secretary's power depends on managing and coping with ethical dilemmas and issues of trust and in putting the best interest of the organisation first:

I enjoy the moral ethical dilemmas, I am always trying to work out what is the best thing to do in this situation. You need to be a diplomat, have thick skin, be resilient and for this you need independence.

Co. sec.

It goes to chairman and chief executive, but maybe the chief executive wants to change it and chairman doesn't.

Co. sec.

Many respondents note that the nature of the role is changing due to developments in reporting requirements, governance, board processes and stakeholder engagement post-financial crisis (2008). The findings illustrate that high-performing company secretaries help to build trust, which results in good governance. Examples may be preparedness for regulatory changes that affect the corporation; being accessible/available to all board members equally; being seen to be 
transparent in business matters, but dealing sensitively with personal director matters (e.g. the NED facinglegalissues on another board, or indicating that they wish to stepdown).

\section{Power}

A company secretary's discretionary power, and to some extent their authority, is defined by how much power the chairman chooses to give:

What you do as company secretary can principally depend on what chairman wants you to do ... company secretary is there to support the chairman.

Chairman

Respondents note that the company secretary has to mould him/her self to fit the relationship with the chairman, but they are also an invisible leader and close trusted advisor to board members. Thus, the company secretary needs to be a good follower-leader in knowing how and when to speak up.

Another power factor for the company secretary stems from knowing the individual board members at a more personal level:

You need to be able to relate to people. The board and executive both trustyou...you act as confidante, advisor, sounding board ... things they might not want to say directly to each other.

$$
\text { Co. sec. }
$$

But, at the same time, the company secretary's power demands an ability to be impartial and unbiased in finding the balance between private and public, or challenging board members for effectiveness:

I use the term Switzerland ... my role is one of neutrality

$$
\text { Co. sec. }
$$

Judgement is sometimes exercised behind the scenes, helping to steer the right direction.

$$
\text { Co. sec. }
$$

The nature of demands placed on the company secretary requires their ability to move from the detail to considering the holistic issue in a broader context:

You need to think very quickly on your feet . . . and be proactive and reactive all the time.

$$
\text { Co. sec. }
$$

Consequently, the company secretary benefits from experience and knowledge in being able to exertpower:

Understanding the business is vital, you don't operate in a vacuum, you need to know what the drivers are.

$$
\text { Co. sec. }
$$


Many respondents note that the power of the company secretary comes to the fore in a crisis, major change situation or when directors fall out with each other. In such cases, the company secretary's power to avoid conflict and find consensus makes the difference between successful outcomes and risk of failure. Examples from high-performing company secretaries may be when the chairman and CEO do not get on, knowing where the expertise lies within the boardroom and getting the right know-how about what to do quickly, or being the independent party between board members that have strong, different, views. The crafting of relations for effectiveness is a continuous process.

\section{Influence}

The majority of respondents agree that being organised and efficient enables the ability to influence and facilitate alliances, even as an observer:

It can be quite powerful to observe and then have a quiet word on the side... Company secretaries can add value by precisely observing dynamics and how it affects decision making.

Each time a new member enters the board there is a new balance of power.

Co. sec.

The power of highly skilled company secretaries emerges in being the primary point of information and its quality for board and governance matters:

You are not only a conduit of information across and between levels, but make sure they get the right information.

Co. sec.

Agenda setting can be a trade off between different priorities. The power of the company secretary in organising pre-meetings, taking minutes and guiding board members' thinking is a subtle process:

Agenda setting is straight forward in that the directors know what they want to say, but you also know what they don't want to talk about and what needs to be discussed ... you can get board and management to talk.

Co. sec.

the board says no but it does not necessarily mean No.

Co. sec.

The ability of the company secretary to influence also arises in that, more often, they are the stability factor and have corporate memory of the issues:

Corporate memory of the change through good times and bad... the tenure of company secretary tends to be longer than CEO these days... suddenly people are looking at you for a view.

Co. sec. 
Underlying this influential power is the fact that the role of the company secretary can be a lonely position, as only they have the depth and understanding of the issue. Further, if they take a stand for the company's interests, it can go against some board members' views. Highly effective company secretaries demonstrate an ability to exercise independent views. Examples may be their active vocal opinions / engagement in board meetings rather than through the chairman; their ability to say 'No' to taking on additional responsibilities; or knowing the inner conversations of different committee meetings, but also knowing the boundaries between them.

Communication and use of language is a critical feature of being able to influence. The majority of respondents agree that company secretaries adopt a non-confrontational, non-threatening, and more subdued and cautious approach to matters:

You've got to be discrete, diplomatic, have integrity ... subtle use of language ... there is a difference between discuss, debate, debate at length, challenge and question.

Co. sec.

I tend to avoid conflict and try and find other ways rather than confrontational.

Co. sec.

You need to be able to read people, understand them and speak their language.

Co. sec.

Highly effective company secretaries generally avoid strong language and are diplomatic in what they say and how they frame it. This even extends to their ability to read peoples personalities and body language, and deal with each person in a different way that is comfortable to the other party.

\section{Company Secretaries' Invisible Leadership as Third-Dimensional Power}

The third-dimensional power of the company secretary emerges as a combination of role, power and influence that combine in giving the company secretary a powerful and unique position as the pivotal role between board and executive management (Table 16.2 below).

In table 16.2, each company secretary's capacity for the 15 characteristics determines their overall level of power heterogeneity that establishes their discretionary power capacity and credibility as part of the team.

In third-dimensional form, power is highly dependent on subtle communication. Human communication is not limited to the message conveyed only by written (Treece, 1972) or chosen spoken words, but embraces paralinguistic characteristics such as voice inflection, acceleration and deceleration, body language and emotional articulation (Watzlawick et al., 2011). The common elements to most communication models are the message senders (i.e. encoder), the message, the channel and the message receiver (i.e. decoder) (Arnold, 1987: 33-34). The company secretary's depth and diversity of communication skills enable better relations to the other board roles as leadership practice. By understanding the other board members as people with personalities first and then engaging with each board member differently to suit their needs, the company secretary is important to building trust amongst board members. The effective company secretary then may support, over a period of time, more openness and quality of dialogue at the board level. This role is therefore always asking how information helps knowledgeable decision making, and what is best and right for the organisation. 
Andrew Kakabadse et al.

Table 16.2 Third-Dimensional Discretionary Power of Company Secretary

\begin{tabular}{|c|c|c|c|}
\hline Characteristics & Role & Power & Influence \\
\hline $\begin{array}{l}\text { Invisible } \\
\text { Leadership }\end{array}$ & $\begin{array}{l}\text { Clarity of } \\
\text { understanding (i) }\end{array}$ & $\begin{array}{l}\text { *Chairman's desire and } \\
\quad \text { relations (i) }\end{array}$ & *Forging alliances (i) \\
\hline \multirow[t]{4}{*}{$\begin{array}{l}\text { Power } \\
\text { Heterogeneity }\end{array}$} & $\begin{array}{l}\text { Structure/position and } \\
\text { standing (i) }\end{array}$ & $\begin{array}{l}\text { Board member } \\
\text { relations (i) }\end{array}$ & $\begin{array}{l}\text { Right and quality } \\
\text { information (i/e) }\end{array}$ \\
\hline & $*$ Self-confidence (i) & Private/Public (i) & $\begin{array}{l}\text { Corporate } \\
\text { memory (i) }\end{array}$ \\
\hline & Ethical resilience (i) & Detail/Holistic (i/e) & Agenda steering (i) \\
\hline & $\begin{array}{l}\text { Adaptability and } \\
\text { preparedness (e) }\end{array}$ & $\begin{array}{l}\text { Experience/Knowledge } \\
\quad \text { (i/e) }\end{array}$ & $\begin{array}{l}\text { Diplomacy in } \\
\text { language and } \\
\text { conduct (i) }\end{array}$ \\
\hline Power tension & Shaping regulation (e) & $\begin{array}{l}\text { Tension as outward } \\
\text { facing (e) }\end{array}$ & Equitable status (e) \\
\hline $\begin{array}{l}\text { How role can better } \\
\text { relate to others for } \\
\text { leadership practice }\end{array}$ & Building trust & Crafting relations & $\begin{array}{l}\text { Having } \\
\text { independence }\end{array}$ \\
\hline
\end{tabular}

Source: Designed by authors from interviews applied to Lukes $(1974,2005)$

(Table key: i - internally focused; e - externally focused; * Dominant characteristic)

The dominant characteristics within table 16.2, from our research, are role-self-confidence; power-chairman desires and relations; influence-ability to forge alliances. These are most commonly critical to company secretaries' power and, interestingly, are all derived within the organisation. Research suggests that the company secretary context is influenced as powerful CEOs or powerful boards prefer engaging similar directors, whereby boards may be more passive or active (Westphal and Zajac, 1995; Westphal and Stern, 2006).

The gaps or tensions in power for the company secretary are that they have less power to shape regulation; lower power on externally facing capacity/stakeholder engagement; and their ability to influence may be constrained due to lack of equitable status amongst the other board members and executives. Interestingly, the power constraints are all derived externally to the organisation.

In board cadres, the quality of individual leadership capacity is commonly observable amongst peers (chair, CEO, SID, NED) as IQ (intelligence) and PQ (political acumen) within the group decision-making setting. Where invisible leadership and follower-leader combine, the company secretary uniquely and consistently engages higher order EQ (emotional) and moral (MQ) skills to a greater level in leadership decision making. However, power is perceived differently with board members seeing words as most important and the company secretary seeing more subtle actions as important (Odhiambo and Hii, 2012). This power often remains as invisible leadership' to the observing stakeholder group. This is why the expectations of other board members of the role of company secretary are often unclear. Our findings indicate that the chairman must actively support and visibly promote the role of the company secretary to other board members on more equitable terms to enable credibility.

Our findings indicate that the role of the company secretary can relate better to other board members, where highly effective company secretaries are able to do a better job by building trust, crafting relations and exercising independence in the role. Where we have focused on the 
company secretary to illustrate the point, these links between role and leadership also require other board members to engage in such practices through regular contact, meeting face to face, bringing wider experiences and expert knowledge to bear, new suggestions and ideas, defending what is right, seeking and adopting best practices, getting to know each other and the organisation, and knowing the strategy and direction in context. It is the daily routines and individual habits that leaders should be improving, adapting and constantly applying to enhance their leadership practices.

\section{Conclusion}

In conclusion, the discretionary capacity and reputation of the company secretary as thirddimensional power is derived internally to the organisation and remains largely 'invisible leadership'. Regardless of the historical narrowing of the powerful secretary role, its renewed corporate form in the $\mathrm{ASCG}^{3}$ framework is emerging with extensions to governance responsibilities (towards $\mathrm{CGO}^{4}$ ). Thus, there is an opportunity to bridge the power tensions between the internal and external demands of the role and the invisible and visible power play in group decision making; and to recognise that all regulatory requirements stretch the nature of power demands. After all, the company secretary is the invisible power behind the throne!

This covert leadership may be preferred by other board members. However, company secretaries may offer more effectiveness through tempered leadership (Roberts et al., 2008) with more visible power. The informal, covert 15 'invisible leadership' characteristics are presently dominated by self-confidence (role); chairman desires (power) and forging alliances (influence). The move towards greater visible power requires the company secretary to seek greater transparency and equitable trust as embodied power in understanding self as part of others (Arja et al., 2013). Without trust, there is a low level of relationship and the company secretary role cannot have the independence to develop itself to the context or as part of a team. Particularly in a crisis or difficult situation, the board is tested and individuals under pressure may revert to their individual type/role rather than focusing on the board as an entity, which can impact on the effectiveness of the board. In consequence, it is more often that the least visible roles within the board become the most critical and their invisible leadership practices contribute more towards consensus in decision making. As such, the company secretary role is able to retain a broader board focus as part of making an individual contribution to the board.

In this chapter, the company secretary has illustrated the link between role and leadership, but this also applies to the rest of the board, as a group of individuals working together. Each role engages with the other roles and the board collectively is effective where the output of the whole leadership team is greater than the output of the sum of the parts. It is this value added that the board should be pursuing as a potential rather than realised contribution and effective performance.

In reality, the company secretary is more likely to be the 'calm amongst the storm', in offering a board contribution that not only resolves conflict issues, but also solves problems of cooperation and co-ordination within the politically contested, powerful arena of board governance and leadership. Ultimately, the independent discretionary mindset of the company secretary as a leader is a necessity that contributes to other board members' perceptions of value, adding to highly effective leadership teams. This is an internally powerful 'invisible leadership' role in the elite corporate board that deserves greater peer and external recognition. 


\section{Notes}

1 Theterm 'company secretary'in theUKand other Commonwealth countries is an equivalent to the US term 'corporate secretary' and to the term 'board secretary' in China.

2 Institute of Chartered Secretaries (ICSA) https:/ / www.icsa.org.uk/

3 Anglo-Saxon corporate governance.

4 Corporate governance officer.

\section{References}

Adams, J. (1996). Principals and Agents, Colonialists and Company Men: The Decay of Colonial Control in the Dutch East Indies. American Sociological Review, 61 (1), 12-28.

Arja, R., Sauer, E. and Salovaara, P. (2013). Embodiment of Leadership through Material Place. Leadership Journal, 9 (3), 378-395.

Armour, D. (2012). The ICSA Company Secretary's Handbook (9th ed.). London: ICSA.

Arnold, V. (1987). The Concept of Process. The Journal of Business Communication, 24 (1), 33-35.

Ashton, H. (2008). The Company Secretary's Handbook: A Guide to Statutory Duties and Responsibilities (5th ed.). London: Kogan Page.

Bachrach, P. and Baratz, M. S. (1970). Power and Poverty: Theory and Practice. New York: Oxford University Press.

Bachrach, P. and Baratz, M. S. (1962). The Two Faces of Power. American Political Science Review, 56 (4), 947-952.

Balkundi, P. and Kilduff, M. (2006). The Ties that Lead: A Social Network Approach to Leadership. The Leadership Quarterly, 17 (4), 419-439.

Baron, R. M. and Kenny, D. A. (1986). The Moderator-Mediator Variable Distinction in Social Psychological Research: Conceptual, Strategic, and Statistical Considerations. Journal of Personality and Social Psychology, 51 (6), 1173-1182.

Beattie, D. (1980). Company Administration Handbook: A Working Companion for General Management and the Company Secretary. A Gower Handbook (4th ed.). Farnborough, Hampshire: Gower Publishing.

Boylan, P. M. A. (1922). Thoth: The Hermes of Egypt. London: Oxford University Press.

Briskin, L. (2011). Union Renewal, Postheroic Leadership, and Women's Organizing: Crossing Discourses, Reframing Debates. Labor Journal, 36 (4), 508-537.

Burton, P. (2000) Antecedents and Consequences of Corporate Governance Structures. Corporate Governance: An International Review, 8 (3), 194-204.

Cadbury, A. (2002). Corporate Governance and Chairmanship. A Personal View. Oxford: Oxford University Press.

Cadbury, A. (1992). Report of the Committee on the Financial Aspects of Corporate Governance [Electronic version]. London: Gee.

Chen, D. (2007). The Behavioural Consequences of CEO-Board Trust and Power Relationships in Corporate Governance. Business Renaissance Quarterly, 2 (4), 59-75.

Cobb, R. W. (1983). Participation in American Politics: The Dynamics of Agenda-Building. Baltimore, MD: Johns Hopkins University Press.

Collinson, D. (2012). Prozac Leadership and the Limits of Positive Thinking. Leadership Journal, 8(2), 87-102.

Corbin, J. M. and Strauss, A. (1990). Grounded Theory Research: Procedures, Canons, and Evaluative Criteria. Qualitative Sociology, 13 (1), 3-21.

Cyert, R. M. and March, J. G. (1963). A Behavioral Theory of the Firm. Englewood Cliffs, NJ: Prentice Hall.

Dahl, R. A. (1957). The Concept of Power. Behavioural Science, 2 (3), 201-214.

Daigneault, M. G. (2006). Innovative Governance: Expand the Nominating Committee's Role to Include Crucial Governance Responsibilities. Credit Union Magazine, January 2006, 44-46.

Dalton, D. R. and Daily, C. M. (1997). CEO and Board Chair Roles Held Jointly or Separately: Much Ado About Nothing? Academy of Management Executive, 11(3), 11-20.

Dubs, R. (2006). Verwaltungsrat-Sitzungen: Grundlegung und Sitzungstechnik. Bern: HauptVerlag.

Epstein, M. (1908). The Early History of the Levant Company. London: George Routledge \& Sons Limited.

Erismann-Peyer, G., Steger, U. and Salzmann, O. (2008). The Insider's View on Corporate Governance: The Role of Company Secretary. Hampshire: Palgrave.

Fama, E. F. and Jensen, M. C. (1983). Separation of Ownership and Control. Journal of Law and Economics, 26, 301-325. 
Filiz, A. (2013). The Company Secretary within the Corporate Governance Framework. Dissertation No. 4145, University of St. Gallen.

Finkelstein, S., Hambrick, D. C., and Cannella, A. A. (2009). Strategic Leadership: Theory and Research on Executives, Top Management Teams, and Boards. New York: Oxford University Press.

Finkelstein, S. and Mooney, A. C. (2003). Not the Usual Suspects: How to Use Board Process to Make Boards Better. Academy of Management Executive, 17, 101-113.

Fletcher, J. and Kaufer, K. (2003). Shared Leadership. In Pearce, C. L. and Conger, J. A. (Eds.), Shared Leadership: Reframing the Hows and Whys ofLeadership (pp. 21-47). Thomas Oaks, CA: Sage.

Forbes, D. P. and Milliken, F. J. (1999). Cognition and Corporate Governance: Understanding Boards of Directors as Strategic Decision-Making Groups. Academy of Management Review, 24 (3), 489-505.

French, J. R. and Raven, B. (1959). Bases of Social Power. In D. Cartwright (Ed.), Studies in Social Power (pp. 15-167). Ann Arbor, MI: Institute of Social Research.

Gallagher, T. J. (2002). The Ethical Case for Chief Governance Officers after 'Enron'. The Corporate Governance Advisor, 10 (4), 41-42.

GepkenJager, E., van Solinge, G. and Timmerman, L. (2005). VOC 1602-2002: 400 Years of Company Law. Law of Business and Finance (Vol. 6). The Netherlands: Kluwer Legal Publishers.

Giddens, A. (1984). The Constitution of Society: Outline of the Theory of Structuration. Los Angeles: University of California Press.

Hannigan, B. (2009). Company Law (2nd ed.). Oxford: Oxford University Press.

Harré, R. and Secord, P. F. (1972). The Explanation of Social Behaviour. Oxford :Blackwell.

Herbert, T. T. (1977). Toward an Administrative Model of the Communication Process. The Journal of Business Communication, 14 (4), 25-35.

Hilb, M. (2011). Integrierte Corporate Governance: Ein neues Konzept der wirksamen Unternehmens-Führung und Aufsicht. Vierteüberarbeitete Auflage. Berlin: Springer-Verlag.

Huse, M. (2005). Accountability and Creating Accountability: A Framework for Exploring Behavioural Perspectives of Corporate Governance. British Journal of Management, 16, S65-S79.

ICSA. (2012). Institute of Chartered Secretaries \& Administrators: Best Practice Guide: Duties of a Company Secretary. ICSA, United Kingdom. http://www.icsa.org.uk/resources/guidance/980803 (accessed 20 January 2014).

Janesick, V. J. (1994). The Dance of Qualitative Research Design: Metaphor, Methodology and Meaning. In N. K. Denzin and Y. S. Lincoln (Eds.), Handbook of Qualitative Research (pp. 209-235). Thousand Oaks, CA: Sage Publications.

Kakabadse, A., Kakabadse, N. and Khan, N. (2014). The Company Secretary. Building Trust through governance. Joint research project and report between Henley Business School and Institute of Company Secretaries and Administrators UK.

Kakabadse, A., Kakabadse, N. and Knyght, R. (2010). The 'Chemistry Factor' in the Chairman/CEO Relationship. European Management Journal, Special Issue: New Leadership Themes, 28 (4), 285-296.

Kakabadse, N. and Louchart, E. (2012). Practical Approach to Elite Interviewing. In A. Kakabadse and N. Kakabadse (Eds.), Elite: The Opaque Nature of Transnational Policy Determination (pp. 286-307). London: Palgrave.

Kaye, J. W. (1853). The Administration of The East India Company. London: Richard Bentley.

Kingsmill, D. (2008). Navigating the Board. Management Today, November 2008, 24.

Ladkin, D. (2013). From Perception to Flesh: A Phenomenological Account of the Felt Experience of Leadership. Leadership Journal, 9(3), 320-334.

Lamm, R. (2003). What's in a Name? CFO - EBSCO Publishing, September 2003, 24.

Levrau, A. and Van den Berghe, L. (2013). Perspectives on the Decision-Making Style of the Board Chair. International Journal of Disclosure and Governance, 10 (2), 105-121.

Lukes, S. (2005). Three Dimensional Power. In S. Lukes (Ed.), Power: A Radical View (2nd Ed.) (pp. 137-151). Basingstoke: Palgrave Macmillan.

Lukes, S. (1974). Power: A Radical View. London: MacMillan Press.

McNulty, T. and Stewart, A. (2014). Developing the Governance Space: A Study of the Role and Potential of the Company Secretary in and around the Board of Directors. Organization Studies, 36 (4), 515-535.

Miles, M. B. and Huberman, A. M.(1994). Qualitative Data Analysis: An Expanded Sourcebook. Thousand Oaks, CA: Sage.

Monks, R. A. G. and Minow, N. (2004). Corporate Governance (3rd ed.). Padstow, Cornwall: TJ International Ltd., Blackwell Publishing. 
Monsted, P. and Garside, G. (1991). The Role of the Company Secretary: A Practical Guide. Institute of Corporate Managers Secretaries and Administrators. Australia: Prentice Hall of Australia Pty Ltd.

Morris, G. D., McKay, S. and Oates, A. (2009). Finance Director's Handbook (5th ed.). Burlington, VA: CIMA Publishing.

Muller, R., Lipp, L. and Pluss, A. (2007). Der Verwaltungsrat: Ein Handbuch fur des Paraxis. Zurich: Schluthess Juristische Medien AG.

Murphy, C. (2003). Radical Company Law Reform: Implications for Researching Companies. Business Information Review, 20 (1), 42-50.

Naval staff, Intelligence Division (1920). A Manual of Netherlands India. London: Oxford University Press.

Odhiambo, G. and Hii, A. (2012). Key Stakeholders' Perceptions of Effective School Leadership. Education, Management and Leadership, 40 (2), 232-247.

Padilla A., Hogan, R. and Kaiser R. (2007). The Toxic Triangle: Destructive Leaders, Susceptible Followers, and Conducive Environments. The Leadership Quarterly, 18 (3), 176-194.

Panorama Developments (Guildford) Ltd v Fidelis Furnishing Fabrics Ltd (1971). Queen's Bench, Vol. 2, 711.

Petra, S. (2005). Do Outside Independent Directors Strengthen Corporate Boards? Corporate Governance, $5(1), 55-64$.

Pettigrew, A. M. (1992). On Studying ManagerialElites. Strategic Management Journal, 13(Winter), 162-182.

Pettigrew, A. M. (1972). Information Control as a Power Resource. Sociology, 6 (2), 187-204.

Polsby, N. W. (1963). Community Power and Political Theory: A Further Look at the Problems of Evidence and Inference. New Haven, CT: Yale University Press.

Pontifex v Bignold (1841). British Columbia Reports, Vol. 3, 63; English Reports, Vol. 133, 1058.

Pontifex v Bignold, (1841). Manning E Granger's Common Pleas Reports (England and Wales), Vol. 3, 63; English Reports, Vol. 133, 1058.

Ramaswami, N. S. (1983). The Chief Secretary: Madras Diaries of Alexander Falconar, 1790-1809. Madras: New Era Publications.

Raven, B. H. (2008). The Bases of Power and the Power/Interaction Model of Interpersonal Influence. Analyses of Social Issues and Public Policy, 8 (1), 1-22.

Roberts, D. D., Roberts, L. M., O’Neil. R. M. and Blake-Beard, S. D. (2008). The Invisible Work of Managing Invisibility for Social Change: Insights from the Leadership of Reverend Dr. Martin Luther King Jr. Business Society Journal, 47 (4), 435-456.

Roberts, J. (2002). Building the Complementary Board. The Work of the plc Chairman. Long Range Planning, 35 (5), 493-520.

Roberts, J., McNulty, T. and Stiles, P. (2005). Beyond Agency Conceptions of the Work of the NonExecutive Director: Creating Accountability in the Boardroom. British Journal of Management, 16, S5-S26.

Rose-Ackerman, S. and Long, C. (1982). Winning the Contest by Agenda Manipulation. Journal of Policy Analysis and Management, 2 (1), 123-125.

Sandberg, J. (2005). How Do We Justify Knowledge Produced within Interpretive Approaches? Organizational Research Methods, 8 (1), 41-68.

Schattschneider, E. E. (1975). Semi-Sovereign People: A Realist's View of Democracy in America. Hinsdale, IL: The Dryden Press.

Schlott, A. (1989). Writing and Writers in Ancient Egypt (Schrift und Schreiber im Alten Ägypten). München: Beck.

Schmidt, E., Schleich, T. and Beck, T. (1988). Merchants as Colonial Masters: Trading World of Dutch at the Cape of Good Hope to Nagasaki, 1600-1800. (Kaufleute als Kolonialherren: Die Handelswelt der Niederländer vom Kap der Guten Hoffnung bis Nagasaki, 1600-1800). Bamberg: C. C. Buchners Verlag.

Schyns, B. and Hansbroughn, T. (Eds.) (2010). When Leadership Goes Wrong. Charlotte, NC: IAP.

Seth, V. K. (2012). The East India Company: A Case Study in Corporate Governance. Global Business Review, 13(2), 221-238.

Severn \& Wye \& Severn Bridge Railway Co (1896). The Times Law Reports, Vol. 12, Chapter 1, p. 262.

Sister Sena, R., Schoorman, D. and Bogotch, I. (2013). Leadership: Doing the Seemingly Impossible. Journal of Cases in Educational Leadership, 16 (2), 33-43.

Steger, U. and Bottger, P. (2008). The Corporate Governance Officer: From Company Secretary to Manager of Governance Processes. In P. Bottger (Ed.). Leading in the Top Team: the CXO challenge (p. 247). Cambridge: Cambridge University Press. 
Treece, M. C. (1972). Business Communications Practices and Problems of Professional Secretaries. Journal of Business Communication, 9 (4), 25-32.

Vance, S. C. (1983). Corporate Leadership: Boards, Directors, and Strategy. New York: McGraw-Hill.

Van der Walt, N. and Ingley, C. (2003). Board Dynamics and the Influence of Professional Background, Gender and Ethnic Diversity of Directors. Corporate Governance, 11, 218-234.

Van Ees, H., Gabrielsson, J. and Huse, M. (2009). Toward a Behavioral Theory of Boards and Corporate Governance. Corporate Governance: An International Review, 17 (3), 307-319.

Van Essen, M., Engelen, P. J. and Carney, M. (2013). Does 'Good'Corporate Governance Help in a Crisis? The Impact of Country- and Firm-Level Governance Mechanisms in the European Financial Crisis. Corporate Governance: An International Review, 21 (3), 201-224.

Watzlawick, P., Bavelas, J. B., and Jackson, D. D. (2011). Pragmatics of Human Communication: A Study of Interactional Patterns, Pathologies and Paradoxes. WW Norton \& Company.

Westphal, J. D. and Stern, I. (2006). The Other Pathway to the Boardroom: Interpersonal Influence Behavior as a Substitute for Elite Credentials and Majority Status in Obtaining Board Appointments. Administrative Science Quarterly, 51 (2), 169-204.

Westphal, J. D. and Zajac, E. J. (1995). Who Shall Govern? CEO/Board Power, Demographic Similarity, and New Director Selection. Administrative Science Quarterly, 40 (1), 60-83.

Young, R. A. (1978). Steven Lukes's Radical View of Power. Canadian Journal of Political Science, 11 (3), 639-649.

Zahra, S. A., Pierce J. A. (1989). Boards of Directors and Corporate Financial Performance: A Review and Integrative Model. Journal of Management, 15, 291-334. 